\title{
PENGARUH MODEL PEMBELAJARAN TTW TERHADAP HASIL BELAJAR MATEMATIKA DENGAN KOVARIABEL KEMAMPUAN NUMERIK DAN VERBAL PESERTA DIDIK KELAS V GUGUS PETULU
}

\author{
N. L. Saraswati Adnyani' ${ }^{1}$, N. Dantes ${ }^{2}$, I M. Ardana ${ }^{3}$ \\ Program Studi Pendidikan Dasar, Program Pascasarjana \\ Universitas Pendidikan Ganesha \\ Singaraja, Indonesia
}

e-mail: \{saraswati.adnyani, nyoman.dantes, made.ardana\}@pasca.undiksha.ac.id

\begin{abstract}
Abstrak
Penelitian ini bertujuan untuk mengetahui besarnya pengaruh model pembelajaran think talk write (TTW) terhadap hasil belajar matematika dengan kovariabel kemampuan numerik dan verbal peserta didik kelas V Gugus Petulu Tahun Pelajaran 2018/2019. Penelitian ini adalah penelitian eksperimen semu dengan rancangan single factor independent groups design with use of covariate. Populasi penelitian ini adalah seluruh peserta didik kelas V SD se-Gugus Petulu yang berjumlah 117 peserta didik. Sebanyak 54 peserta didik dipilih sebagai sampel yang ditentukan dengan teknik random sampling. Data hasil belajar matematika menggunakan tes pilihan ganda dan data kemampuan numerik dan kemampuan verbal peserta didik diperoleh dari tes kecerdasan numerik dan tes kemampuan verbal. Data dianalisis dengan menggunakan ANACOVA berbantuan SPSS 17.00 for windows. Hasil penelitian menunjukkan bahwa: Pertama, terdapat pengaruh implementasi model pembelajaran think talk write (TTW) terhadap hasil belajar Matematika. Kedua, dengan pengendalian kemampuan numerik terdapat pengaruh implementasi model pembelajaran think talk write (TTW) terhadap hasil belajar Matematika. Ketiga, dengan pengendalian kemampuan verbal terdapat pengaruh implementasi model pembelajaran think talk write (TTW) terhadap hasil belajar Matematika. Keempat, dengan pengendalian kemampuan numerik dan verbal secara simultan terdapat pengaruh implementasi model pembelajaran think talk write (TTW) terhadap hasil belajar Matematika. Kelima, terdapat kontribusi kemampuan numerik terhadap hasil belajar Matematika. Keenam, terdapat kontribusi kemampuan verbal terhadap hasil belajar Matematika. Ketujuh, terdapat kontribusi kemampuan numerik dan verbal secara simultan terhadap hasil belajar Matematika.
\end{abstract}

Kata kunci: hasil belajar Matematika, kemampuan numerik, kemampuan verbal, think talk write

\begin{abstract}
This study aims to determine the effect of think talk write (TTW) learning model on mathematics learning outcomes with covariable numerical and verbal abilities of fifth grade students of Cluster Petulu 2018/2019 Academic Year. This research is a quasiexperimental study with a single factor design of independent groups design with use of covariate. The population of this research was all of the fifth grade elementary school students in Cluster Petulu, amounting to 117 students. A total of 54 students were selected as samples determined by random sampling techniques. Data on mathematics learning outcomes using multiple choice tests and data on students' numerical abilities and verbal abilities are obtained from numerical intelligence tests and verbal ability tests. Data were analyzed using assisted ANACOVA SPSS 17.00 for windows. The results showed that: First, there was the effect of implementing the think talk write (TTW) learning model on Mathematics learning outcomes. Second, with numerical ability control there is the influence of the implementation of the think talk write (TTW) learning model
\end{abstract}


on Mathematics learning outcomes. Third, by controlling verbal abilities there is the influence of the implementation of the think talk write (TTW) learning model on Mathematics learning outcomes. Fourth, by controlling numerical and verbal abilities simultaneously there is the influence of the implementation of the think talk write (TTW) learning model on Mathematics learning outcomes. Fifth, there is a contribution of numerical abilities to the learning outcomes of Mathematics. Sixth, there is a contribution of verbal ability to the results of learning Mathematics. Seventh, there is a simultaneous contribution of numerical and verbal abilities to the learning outcomes of Mathematics.

Kata kunci: Mathematics learning outcomes, numeric abilities, verbal abilities, think writewrite

\section{PENDAHULUAN}

Penguasaan matematika dapat
ditunjukkan dengan hasil belajar
matematika peserta didik. Hasil belajar
dapat dijadikan salah satu tolok ukur
keberhasilan pembelajaran. Hasil belajar yang tinggi, menunjukkan bahwa pembelajaran sudah terlaksana dengan baik. Sebaliknya, rendahnya hasil belajar menunjukkan bahwa perlu adanya koreksi dan perbaikan terhadap pelaksanaan pembelajaran. Adakalanya peserta didik menjawab soal dengan benar namun mereka tidak dapat mengungkapkan alasan dari jawaban mereka. Ketika diberikan soal cerita, peserta didik tidak mengetahui operasi apa yang terdapat dalam soal tersebut, baik itu penjumlahan, pengurangan, perkalian dan pembagian. Peserta didik dapat menggunakan rumus tetapi tidak tahu dari mana asalnya rumus tersebut dan mengapa rumus tersebut digunakan. Keadaan demikian terjadi karena di dalam proses pembelajaran peserta didik kurang diberi kesempatan dalam mengungkapkan ide-ide dan alasan dari jawaban mereka sehingga mereka kurang terbiasa mengungkapkan ide-ide atau alasan dari jawabannya.

Hal itu menunjukkan bahwa terdapat keragaman dalam hal penguasaan matematika peserta didik. Keragaman tersebut diduga terjadi karena berbagai faktor, antara lain kemampuan peserta didik dalam matematika. Kemampuan matematika meliputi beberapa kemampuan yaitu komunikasi matematis, penalaran matematis, pemecahan masalah, koneksi matematis, dan representasi matematis (Daniyati \& Sugiman, 2015). Adapun kemampuan matematika yang perlu dikuasai peserta didik adalah kemampuan komunikasi matematika dan kemampuan dalam melakukan perhitungan matematis . Untuk dapat berkomunikasi matematis, peserta didik perlu menguasai kemampuan verbal sedangkan untuk bisa melakukan perhitungan peserta didik harus menguasai kemampuan numerik.

Irawan \& Kencanawaty (2016) menyatakan kemampuan verbal adalah kemampuan yang dimiliki seseorang untuk menjelaskan pemikirannya dan mengaitkan informasi yang diperolehnya serta dapat membuat suatu hipotesis. Kemampuan verbal yang baik diduga memiliki kecakapan yang mensyaratkan keakraban dengan bahasa tertulis maupun lisan untuk menyimak, menelaah isi dari suatu pernyataan, berani mengungkapkan ide, gagasan, pendapat, dan pikirannya,sehingga peserta didik tersebut dapat mengambil suatu kesimpulan yang tepat. Sedangkan Irawan (2016) menyatakan kemampuan verbal adalah suatu kemampuan yang dimiliki oleh seseorang dalam bentuk lisan dan tulisan berupa kata-kata yang dapat menjadi alat komunikasi pada diri sesorang dan sebagan bahan pemberi dan penerima informasi yang diberikan oleh seseorang.

Menurut Fatimah (2015) terdapat interaksi antara kemampuan verbal dengan prestasi belajar kognitif produk, dan tidak ada interaksi antara kemampuan verbal dengan prestasi belajar proses dan afektif peserta didik. Hal ini menunjukkan bahwa peserta didik yang memiliki kemampuan verbal dengan baik memiliki pengaruh positif terhadap prestasi belajar kognitif produk. Dari penjabaran tersebut dapat disimpulkan bahwa yang dimaksud dengan 
kemampuan verbal adalah kemampuan yang dimikili oleh seseorang untuk menjelaskan isi pemikirannya dalam bentuk tulisan ataupu lisan yang dapat memberikan pengaruh terhadap hasil belajar peserta didik.

Kemampuan verbal diperlukan dalam setiap mata pelajaran, salah satunya matematika. Hal itu dikarenakan di dalam matematika banyak sekali simbol yang digunakan, baik berupa huruf maupun nonhuruf. Kemampuan verbal akan membantu peserta didik dalam memahami makna dan membuat model matematika untuk menyelesaikan permasalahan matematika tersebut. Apabila kemampuan verbal peserta didik kurang baik, maka peserta didik juga akan sulit dalam menyelesaikan soal matematika sehingga secara tidak langsung akan berdampak pada pencapaian hasil belajar. Oleh karena itu, kemampuan verbal ini sangat erat hubungannya dengan hasil belajar. Penelitian Daniyati \& Sugiman (2015) memperoleh hasil bahwa kemampuan verbal peserta didik memberi kontribusi yang cukup besar terhadap hasil belajar peserta didik .

Selain kemampuan verbal, hasil belajar matematika peserta didik juga dipengaruhi oleh kelampuan numerik yang dimiliki peserta didik itu sendiri. Kemampuan numerik yang dimaksudkan adalah kemampuan berpikir, mengorganisasi informasi untuk menyelesaikan masalah yang berkaitan dengan angka. Gunarti (2017) menyatakan kemampuan numerik adalah potensi yang dimiliki seseorang untuk memecahkan masalah yang berhubungan dengan berhitung. Kemampuan numerik meliputi kemampuan menghitung dalam hal penjumlahan, kemampuan menghitung dalam hal pengurangan, kemampuan menghitung dalam hal perkalian, dan kemampuan menghitung dalam hal pembagian. Kemampuan numerik juga diartikan sebagai kemampuan yang dimiliki oleh seseorang untuk menggunakan angkaangka, melakukan perhitungan dan merubah permasalahan uraian cerita menjadi angka-angaka yang selanjutnya dapat dilakukan perhitungan dengan matematika (Irawan \& Kencanawaty, 2016).

Kemampuan numerik tersebut merupakan kemampuan khusus dalam hitung menghitung. John W. Santrock (dalam Kusuma \& Budiono, 2015) menyatakan, "keahlian matematika adalah kemampuan untuk menyelesaikan operasi matematika". Sebagian besar materi yang ada dalam mata pelajaran matematika membutuhkan banyak penghitungan dan membutuhkan kemampuan khusus yang mempengaruhi hasil belajar matematika. Hal yang paling mendasar dalam belajar matematika adalah diperlukannya kemampuan numerik atau kemampuan berhitung peserta didik. Dari beberapa pendapat tersebut dapat disimpulkan bahwa kemampuan numerik adalah kemampuan berhitung atau mengolah angka yang dimiliki setiap orang dengan tingkatan yang berbeda-beda. Kelemahan umum peserta didik Sekolah Dasar dalam kemampuan numerik ini adalah masih kurangnya keterampil peserta didik untuk berhitung. Oleh karena itu kemampuan berhitung peserta didik Sekolah Dasar masih sering menjadi permasalahan. Kemampuan numerik dapat ditingkatkan melalui latihan-latihan secara teratur dan mencoba berbagai macam hitungan sehingga pada akhirnya dapat menemukan cara-cara baru dalam kalkulasi bilangan. Hal ini sejalan dengan penelitian yang dilakukan oleh Irawan \& Kencanawati (2016). Dari penelitian tersebut, Irawan \& Kencanawati menemukan bahwa terdapat pengaruh yang signifikan antara kemampuan verbal dan kemampuan numerik secara bersama-sama terhadap kemampuan berpikir kritis matematika.

Rendahnya hasil belajar peserta didik juga dipengaruhi oleh faktor eksternal berupa metode, model serta strategi yang digunakan dalam proses belajar mengajar. Mayoritas metode yang digunakan oleh guru masih berupa metode ceramah sehingga sebagian besar peserta didik menjadi kurang tertarik untuk menyimak materi yang sedang dijelaskan dan enggan untuk bertanya serta mengemukakan pendapatnya terkait materi tersebut pada saat proses pembelajaran. Hal seperti ini 
akan memberikan pengaruh negatif pada hasil belajar peserta didik. Proses pembelajaran sendiri pada hakikatnya untuk mengembangkan aktivitas dan kreativitas peserta didik melalui berbagai interaksi dan pengalaman belajar. Seperti yang dinyatakan oleh Mulyasa bahwa proses pembelajaran pada satuan pendidikan diselenggarakan secara interaktif, inspiratif, menyenangkan, menantang, memotivasi peserta didik untuk berpartisipasi aktif, serta memberikan ruang yang cukup bagi prakarsa, kreativitas dan kemandirian sesuai dengan bakat, minat, dan perkembangan fisik dan psikologis peserta didik. Adanya penggunaan metode, model serta strategi pembelajaran yang kurang tepat tersebut menyebabkan peserta didik menjadi jarang untuk mencatat serta memahami informasi atau pengetahuan apa saja yang menjadi pengetahuan baru bagi mereka.

Selain itu, hasil observasi yang saya lakukan di SD gugus Petulu juga menunjukkan rendahnya hasil belajar matematika peserta didik kelas $\mathrm{V}$ ketika mengikuti Ulangan Umum Semester I tahun pelajaran 2018/2019. Peserta didik juga terkesan tidak menyukai pelajaran matematika bahkan ada yang takut akan pelajaran matematika karena dianggap menyeramkan.

Agar hasil serta proses belajar dan mengajar dapat berhasil dengan baik, perlu adanya metode, model serta strategi yang tepat dalam proses belajar dan mengajar yang dilakukan oleh peserta didik dan guru. Untuk memilih suatu model pengajaran perlu memperhatikan beberapa hal seperti materi yang akan disampaikan, tujuannya, waktu yang tersedia dan banyaknya peserta didik serta hal-hal berkaitan dengan proses belajar mengajar. Model pembelajaran yang dapat mendorong peserta didik untuk ikut aktif adalah model pembelajaran kooperatif. Menurut Slavin pembelajaran kooperatif adalah pembelajaran yang dilakukan secara berkelompok, peserta didik dalam satu kelas dijadikan kelompok-kelompok kecil yang terdiri dari 3 sampai 5 orang untuk memahami konsep yang difasilitasi oleh guru.
Dalam pembelajaran kooperatif
terdapat berbagai macam tipe pembelajaran, salah satunya adalah model pembelajaran Think Talk Write (TTW). Model pembelajaran TTW yang diperkenalkan oleh Huinker dan Laughin, pada dasarnya dibangun melalui berpikir, berbicara dan menulis. Penerapan TTW memungkinkan seluruh peserta didik mengeluarkan ide-ide, membangun secara tepat untuk berpikir dan refleksi, mengorganisasi ide-ide, serta mengetes ide tersebut sebelum peserta didik diminta untuk menulis. Selain itu, dalam model ini peserta didik dapat mengembangkan pengetahuan, keterampilan, dan kompetensi sikap sosial peserta didik yang ditunjukkan melalui perilaku jujur, disiplin, tanggungjawab, santun, peduli, dan percaya diri dalam berkomunikasi (Siregar, 2017).

Model ini dikembangkan dari keterlibatan peserta didik dari proses berpikir setelah membaca, selanjutnya berbicara, dan membagi ide (sharing) dengan teman lain atau dalam kelompok kemudian mengungkapkan dalam tulisan atau rangkuman sesuai dengan kreativitasnya. Pada proses belajar terjadi aktivitas berpikir, berkomunikasi dan mengkonstruksi ide berdasarkan pemahaman dan pengetahuan yang diperolehnya. Dengan model pembelajaran ini diharapkan peserta didik terlibat aktif, baik secara individual maupun dalam kelompok belajar.

Model pembelajaran Think Talk Write (TTW) ini sudah cukup sering dijadikan variabel penelitian yang dipadukan dengan variabel lainnya dan memperoleh hasil yang menunjukkan bahwa penerapan model ini memberikan pengaruh yang positif terhadap hasil belajar peserta didik. Salah satunya adalah penelitian yang dilakukan oleh Wirda mahapeserta didik S2 UNIMED (2017) yang melakukan penelitian dengan judul "the effect of think talk write (ttw) learning method on thecreative thinking ability of the students at primary school (SD) no. 060856 medan, indonesia" memperoleh hasil bahwa peserta didik yang belajar dengan model pembelajaran TTW jauh lebih baik daripada peserta didik yang 
belajar dengan model pembelajaran konvensional yang dapat dilihat dari nilai rata-rata kelas yang diperoleh oleh masingmasing kelompok. Kelompok model TTW rata-ratanya 80,67 sedangkan kelompok konvensional memperoleh rata-rata 68,97. Namun, berdasarkan hasil penelitian Budi Purwanto yang dikemukakan oleh Novia Fajar Utami (2014) mahapeserta didik S2 Universitas Sebelas Maret menyatakan bahwa peserta didik yang diberikan model pembelajaran TPS dan TTW memiliki prestasi belajar yang sama. Dari hasil penelitian ini peneliti ingin mengembangkan model pembelajaran TTW agar mengetahui apakah model ini memang baik atau tidak digunakan dalam pembelajaran di kelas.

Berdasarkan latar belakang tersebut, penulis tertarik untuk mengadakan penelitian dengan judul: "Pengaruh Model Pembelajaran Think Talk Write (Ttw) Terhadap Hasil Belajar Matematika Dengan Kovariabel Kemampuan Numerik Dan Verbal Peserta didik Kelas $V$ Gugus Petulu Tahun Pelajaran 2018/2019".

\section{METODE PENELITIAN}

Jenis penelitian ini adalah penelitian quasi eksperimen. Iskandar (2010:64) menjelaskan bahwa penelitian eksperimen adalah merupakan suatu penelitian yang menuntut peneliti memanipulasi dan mengendalikan satu atau lebih variabel bebas serta mengamati variabel terikat, untuk melihat perbedaan sesuai dengan manipulasi variabel bebas tersebut atau penelitian yang melihat hubungan sebab akibat kepada dua atau lebih variabel dengan memberi perlakuan lebih (treatment) kepada kelompok eksperimen. Desain penelitian eksperimen yang digunakan adalah quasi eksperimen (eksperimen semu). Pemilihan quasi eksperimen disebabkan oleh keterbatasan kemampuan untuk mengubah kondisi kelas yang sudah terbentuk sebelumnya. Desain penelitian eksperimen semu yang digunakan adalah Single Factor Independent Groups Design with use of Covariate yang merupakan adaptasi dari desain Dantes (2012:96).

Populasi penelitian ini adalah seluruh peserta didik kelas V SD se-gugus Petulu.
Gugus Petulu terdiri dari 3 SD yaitu: SD N 1 Petulu, SD N 2 Petulu, SD N 3 Petulu dan SD Suta Dharma yang berjumlah 117 orang. Uji kesetaraan kelas dilakukan sebelum eksperimen dilakukan pada kelas-kelas yang telah ditentukan. Uji ini dilakukan untuk memastikan bahwa kelas-kelas atau grup-grup yang dipakai untuk pengambilan data adalah berasal dari grup-grup yang memiliki kemampuan yang setara atau sama. Untuk mengetahui kesetaraan ini, uji Anava Satu Jalan digunakan dalam penganalisisan data sebelum eksperimen dilakukan.

Aplikasi SPSS digunakan untuk memproses uji Anava Satu Jalan untuk uji kesetaraan kelas pada penelitian ini. Apabila hasil analisis menunjukan hasil yang tidak signifikan $(p>0,05)$ maka dapat disimpulkan bahwa grup-grup tersebut adalah setara dan dapat digunakan untuk penelitian ini.

Pemilihan sampel dilakukan dengan teknik random sampling dengan jumlah 54 orang peserta didik, yang dirandom adalah kelasnya. Teknik random sampling digunakan untuk menentukan kelompok eksperimen dan kelompok kontrol. Untuk menentukan sampel yang digunakan, terlebih dahulu dilakukan penyetaraan pada seluruh kelas yang menjadi populasi penelitian. Penyetaraan menggunakan nilai Ulangan Umum semester genap agar lebih representatif terhadap kemampuan peserta didik.

Variabel bebas dalam penelitian ini adalah model pembelajaran Think Talk Write (TTW) yang digunakan pada kelompok eksperimen sedangkan untuk kelompok kontrol digunakan pembelajaran konvensionalberpendekatan saintifik. Selain variabel bebas, variabel terikat merupakan hal penting yang harus ditentukan dalam sebuah penelitian. Variabel terikat menunjukkan fokus dari sebuah penelitian. Dalam penelitian ini yang menjadi variabel terikat adalah hasil belajar Matematika peserta didik. Variabel control merupakan variabel yang memengaruhi (memperkuat dan memperlemah) hubungan antara variabel bebas dengan variabel terikat (Sugiyono, 2014). Variabel kontrolyang ditetapkan dalam penelitian ini adalah 
kemampuan numerik dan kemampuan verbal peserta didik.

Data yang dikumpulkan dalam penelitian ini adalah data kemampuan numerik dankemampuan verbalserta hasil belajar matematika. Data kemampuan kemampuan numerik dankemampuan verbalpeserta didik diperoleh dari tes kecerdasan numerik dan tes kemampuan verbal. Data hasil belajar matematika peserta didik diperoleh dari tes yang diberikan setelah perlakuan atau treatment. Dengan demikian metode pengumpulan data dalam penelitian ini adalah metode tes.

Suatu instrumen penelitian dikatakan baik jika sudah memenuhi dua persyaratan penting yaitu valid dan reliabel (Suharsimi Arikunto, 2006). Instumen yang valid/sahih adalah instrumen yang mampu mengukur apa yang diinginkan oleh peneliti dan dapat mengungkap data dari variabel yang diteliti secara tepat. Uji coba tes akan dilakukan di kelas V semester II (genap) di SD gugus Petulu yang tidak digunakan sebagai sampel penelitian. Instrumen penelitianterlebih dahulu dilakukan uji prasyarat instrument yang meliputi: uji validitas, reliabilitas, taraf kesukaran dan daya beda.

Untuk mengetahui apakah data yang telah didapatkan memenuhi persyaratan, maka perlu dilakukan analisis menggunakan teknik analisis yang ditetapkan. Sebelum melakukan uji hipotesis maka harus dilakukan beberapa uji statistik diskriptif dan uji prasyarat.

Teknik analisis deskriptif yaitu statistik yang digunakan untuk menggambarkan atau menganalisis suatu statistik hasil penelitian tetapi tidak digunakan untuk generalisasi/inferensi. Teknik analisis ini digunakan untuk mengetahui tinggi rendahnya kualitas dari hasil belajar matematika peserta didik. Analisis deskriptif yang digunakan adalah mean, median, modus, dan standar deviasi.

Uji prasyarat analisis yang dilakukan adalah uji normalitas data, uji homogenitas varians, dan uji linearitas. Analisis statistik yang digunakan untuk menguji hipotesis adalah menggunakan anava, anakova satu jalur, serta analisis regresi dengan bantuan SPSS 17.00 for windows.

\section{HASIL PENELITIAN DAN PEMBAHASAN}

Hasil uji hipotesis pertama telah berhasil menolak hipotesis nol yang menyatakan bahwa terdapat pengaruh implementasi model pembelajaran ThinkTalk-Write (TTW) terhadap hasil belajar Matematika peserta didik kelas V SD gugus Petulu tahun pelajaran 2018/2019. Harga $F_{\text {hit. }}$ diketahui bahwa nilai $F_{\text {hit }}=70,617$ dengan taraf signifikansi dibawah 0,05. Selanjutnya, apabila ditetapkan taraf signifikansi $\alpha=0,05$, maka nilai sig. lebih kecil dari taraf signifikansi (sig. $=0,000<$ $\alpha=0,05$ ).

Model Pembelajaran Think Talk Write
(TTW) memberikan peserta didik
keleluasaan dalam mengkonstruksi
pemikiran yang berbeda antara peserta didik satu dengan peserta didik lain dalam kolaborasi kelompok untuk menemukan strategi yang efektif dalam penyelesaian soal. Dapat dilihat dari bagan bahwa setiap tahapan dalam model pembelajaran ini dapat melatih setiap aspek hasil belajar yang ingin dihasilkan. Misalnya pada tahap peserta didik berdiskusi dalam kelompok untuk membahas isi catatan dan menyelesaikan soal tersebut.

Ketika proses berdiskusi akan melatih kemampuan peserta didik pada aspek kognitif (pengetahuan yang dimiliki), afektif (bagaimana peserta didik bisa berkomunikasi dengan teman yang lain serta menghargai teman), dan psikomotor (bagaimana peserta didik mampu mengungkapkanpendapatnya).

Berdasarkan uraian tersebut diduga model pembelajaran Think Talk Write (TTW) memungkinkan meningkatkan hasil belajar matematika peserta didik.

Hasil penelitian ini sejalan dengan penelitian yang dilakukan oleh Lidya, dkk (2017) yang berjudul Pengembangan Karakter dan Hasil Belajar Kognitif Peserta didik dengan Pembelajaran Think Talk Write Dipadu Problem Based Learning memperoleh hasil: (1) ada pengaruh pembelajaran Biologi dengan model pembelajaran TTW dipadu PBL terhadap karakter peserta didik dapat dilihat dari perolehan $\mathrm{F}$ hitung 24,553 dengan nilai sig. $0,000<0,05$. (2) ada pengaruh 
pembelajaran Biologi dengan model pembelajaran TTW dipadu PBL terhadap hasil belajar kognitif peserta didik yang dapat dilihat dari perolehan $\mathrm{F}$ hitung 78,605 dengan nilai sig. 0,000<0,05.

Dengan demikian dapat dikatakan bahwa terdapat perbedaan hasil belajar matematika antara peserta didik yang mengikuti pembelajaran Think Talk Write (TTW) dengan peserta didik yang mengikuti pembelajaran konvensional.

Hasil uji hipotesis kedua telah berhasil menolak hipotesis nol yang menyatakan bahwa dengan pengendalian kemampuan numerik terdapat pengaruh implementasi model pembelajaran Think Talk Write (TTW) terhadap hasil belajar Matematika peserta didik kelas V SD gugus Petulu tahun pelajaran 2018/2019. harga $F_{\text {hit }}=12,230$ dengan taraf signifikansi di bawah 0,05. Selanjutnya, apabila ditetapkan taraf signifikansi $\alpha=0,05$, maka nilai sig. lebih kecil dari taraf signifikansi (sig. $=0,001<$ $\alpha=0,05)$. Jadi dapat disimpulkan bahwa dengan pengendalian kemampuan numerik terdapat pengaruh implementasi model pembelajaran Think Talk Write (TTW) terhadap hasil belajar Matematika peserta didik kelas V SD gugus Petulu tahun pelajaran 2018/2019.

Kemampuan numerik adalah pemahaman dan nalar di bidang yang berkaitan dengan angka-angka. Dalam melakukan penalaran peserta didik terlebih dahulu harus membaca angka ataupun soal tersebut sehingga mampu memaknai maksud dan tujuan dari soal sebelum soal tersebut dikerjakan. Peserta didik yang memiliki kemampuan numeric yang baik akan cepat mampu melakukan perhitungan dengan tepat setelah ia memahami soal. Sedangkan peserta didik yang memiliki kemampuan numeric yang tidak baik maka akan kesulitan dalam melakukan perhitungan. Maka dari itu, untuk memperoleh hasil yang murni peneliti mengendalikan kemampuan numerik peserta didik.

Berdasarkan uraian di atas, dapat dikatakan terdapat interaksi antara pembelajaran matematika yang menggunakan model Think Talk Write
(TTW)dengan kemampuan numerik peserta didik.

Hasil uji hipotesis ketiga telah berhasil menolak hipotesis nol yang menyatakan bahwa dengan pengendalian kemampuan verbal terdapat pengaruh implementasi model pembelajaran Think Talk Write (TTW) terhadap hasil belajar Matematika peserta didik kelas $V$ SD gugus Petulu tahun pelajaran 2018/2019. Harga $F_{\text {hit }}=18,378$ dengan taraf signifikansi di bawah 0,05. Selanjutnya, apabila ditetapkan taraf signifikansi $\alpha=0,05$, maka nilai sig. lebih kecil dari taraf signifikansi (sig. $=0,000<$ $\alpha=0,05)$. Jadi dapat disimpulkan bahwa dengan pengendalian kemampuan verbal terdapat pengaruh implementasi Model Pembelajaran Thin Talk Write (TTW) terhadap hasil belajar Matematika peserta didik kelas V SD gugus Petulu tahun pelajaran 2018/2019.

Dalam mengerjakan soal peserta didik terlebih dahulu harus membaca angka ataupun soal tersebut sehingga mampu memaknai maksud dan tujuan dari soal sebelum soal tersebut dikerjakan. Ketika membaca soal setidaknya peserta didik sudah menguasai ejaan, tata bahasa, mampu mengartikan kata, mampu mengisi kalimat yang rumpang dan kosakata terutama sinonim (persamaan kata) serta antonim (lawan kata) untuk membantu dalam memaknai kalimat yang dibaca. Peserta didik yang memiliki kemampuan verbal yang baik akan lebih cepat dalam memahami soal daripada peserta didik yang memiliki kemampuan verbal yang tidak baik.

Berdasarkan uraian di atas, dapat dikatakan bahwa terdapat interaksi antara pembelajaran matematika yang menggunakan model Think Talk Write (TTW) dengan kemampuan verbal peserta didik.

Hasil uji hipotesis keempat telah berhasil menolak hipotesis nol yang menyatakan bahwa dengan pengendalian kemampuan numerik dan verbal secara simultan terdapat pengaruh implementasi model pembelajaran Think Talk Write (TTW) terhadap hasil belajar Matematika peserta didik kelas $V$ SD gugus Petulu tahun pelajaran 2018/2019. Harga $F_{\text {hit }}=12,108$ 
dengan taraf signifikansi di bawah 0,05. Selanjutnya, apabila ditetapkan taraf signifikansi $\alpha=0,05$, maka nilai sig. lebih kecil dari taraf signifikansi (sig. $=0,001<$ $\alpha=0,05)$. Jadi dapat disimpulkan bahwa dengan pengendalian kemampuan numerik dan verbal secara simultan terdapat pengaruh implementasi Model Pembelajaran Think Talk Write (TTW) terhadap hasil belajar Matematika peserta didik kelas V SD gugus Petulu tahun pelajaran 2018/2019.

Dengan model pembelajaran Think Talk Write (TTW) yang memfokuskan pada kemampuan berfikir, berbicara/berkomunikasi, dan menulis peserta didik dengan mendendalikan kemampuan numerik seperti kemampuan melakukan perhitungan penjumlahan, pengurangan dan perkalian serta pengendalian kemampuan verbal berupa kemampuan peserta didik menyusun kalimat dalam menjawab soal, pemahaman peserta didik terhadap tata bahasa yang digunakan serta pemahaman terhadap bahasa yang digunakan diharapkan mampu memperoleh hasil belajar matematika yang baik. Dalam melakukan perhitungan peserta didik harus mampu memahami bahasa dari soal tesebut, setelah paham peserta didik harus mampu memikirkan cara penyelesaiannya dengan berkomunikasi baik dengan teman ataupun gurunya. Setelah itu ia mampu menuliskan pemikirannya tersebut. Jika semua proses dapat dilalui oleh peserta didik maka selain memperoleh pengetahuan (kognitif) peserta didik juga akan melatih aspek afektifnya dari belajar menerima dan menghargai pendapat orang lain serta aspek psikomotornya yaitu mampu mengemukakan pendapat dan tampil dimuka umum.

Hasil uji hipotesis kelima telah berhasil menolak hipotesis nol yang menyatakan bahwa terdapat kontribusi kemampuan numerik terhadap hasil belajar Matematika peserta didik kelas V SD Gugus Petulu tahun pelajaran 2018/2019. Nilai sig. adalah 0,644 , lebih besar dari $\alpha=$ 0,05 (sig. $=0,644>\alpha=0,05$ ). Maka Ho ditolak dan $\mathrm{H}_{1}$ diterima. Jadi, dapat disimpulkan bahwa terdapat kontribusi kemampuan numerik terhadap hasil belajar Matematika peserta didik kelas V SD Gugus Petulu tahun pelajaran 2018/2019. Selanjutnya, bagian tabel $R^{2}$ menujukan seberapa besar kontribusi kemampuan numerik peserta didik terhadap hasil belajar matematika. Pada tabel di atas, diketahui bahwa kemampuan numerik peserta didik berkontribusi sebesar 59,6\%.

Banyak faktor yang dianggap mempengaruhi hasil belajar, dalam hal ini adalah kecerdasan numerik yang dimiliki peserta didik itu sendiri. Pada pelajaran matematika khususnya, kecerdasan numerik sangat berperan penting dalam keberhasilannya. Kecerdasan numerik yang berkembang dengan baik dalam diri peserta didik mampu membantu peserta didik dalam menyelesaikan soal-soal matematika. Dari uraian di atas dimungkinkan adanya pengaruh signifikan antara kecerdassan numerik peserta didik terhadap hasil belajar matematika. Dapat pula dikatakan bahwa kemampuan numerik yang dimiliki oleh peserta didik itu sendiri memiliki kontribusi terhadap hasil belajar matematika yang diperoleh oleh peserta didik.

Hasil uji hipotesis keenam telah berhasil menolak hipotesis nol yang menyatakan bahwa terdapat kontribusi kemampuan verbal terhadap hasil belajar Matematika peserta didik kelas V SD Gugus Petulu tahun pelajaran 2018/2019. nilai sig. adalah 0,742 , lebih besar dari $\alpha=$ 0,05 (sig. $=0,742>\alpha=0,05$ ). Maka Ho ditolak dan $\mathrm{H}_{1}$ diterima. Jadi, dapat disimpulkan bahwa terdapat kontribusi kemampuan verbal terhadap hasil belajar Matematika peserta didik kelas V SD Gugus Petulu tahun pelajaran 2018/2019. Selanjutnya, bagian tabel $\mathrm{R}^{2}$ menujukan seberapa besar kontribusi kemampuan verbal peserta didik terhadap hasil belajar matematika. Pada tabel di atas, diketahui bahwa kemampuan numerik peserta didik berkontribusi sebesar $68,7 \%$.

Salah satu kesulitan peserta didik dalam pelajaran matematika adalah dalam memahami soal cerita. Salah satu faktor penyebabnya adalah kurangnya kemampuan verbal yang dimiliki oleh peserta didik. Kemampuan verbal merupakan salah satu karakteristik yang 
dimiliki peserta didik, sebagai potensi yang turut mempengaruhi efektivitas proses belajar, karena itu aspek ini juga perlu mendapat perhatian guru dalam pembelajaran. Dilihat dari segi kemampuan verbal peserta didik dalam menganggapi pelajaran yang diberikan juga bervariasi, ada yang tinggi, sedang dan ada yang rendah. Hal ini disebabkan oleh kemampuan dalam menerima dan mentransfer informasi yang diperoleh mempunyai tingkatan yang berbeda-beda.

Selain itu, kemampuan verbal juga mencakup kemampuan membaca, kemampuan memahami bacaan yang selanjutnya diharapkan mampu menyusun kembali ke dalam bahasanya sendiri sesuai dengan tingkat perkembangan intelektualnya. Berdasarkan hal itu jelaslah bahwa kemampuan verbal merupakan karakteristik peserta didik yang banyak berpengaruh terhadap proses belajar matematika, sehingga karakteristik peserta didik ini perlu mendapat perhatian di dalam meningkatkan pemahaman peserta didik dalam pembelajaran.

Dari uraian tersebut dapat kita simpulkan bahwa jika kemampuan verbal peserta didik baik maka hasil belajar matematika peserta didik akan baik pula. Namun, jika kemampuan verbal peserta didik buruk maka hasil belajar matematika peserta didik juga akan buruk. Oleh karena itu, dapat dikatakan bahwa kemampuan verbal peserta didik memberikan kontribusi tehadap hasil belajar matematika yang dicapai.

Hasil uji hipotesis ketujuh telah berhasil menolak hipotesis nol yang menyatakan bahwa terdapat kontribusi kemampuan numerik dan verbal secara simultan terhadap hasil belajar Matematika peserta didik kelas V SD gugus Petulu tahun pelajaran 2018/2019. Dari hasil analisis data tersebut dapat dilihat $F$ hitung sebesar 64,272 lebih besar dari $F$ tabel sebesar 4,02. $F$ hitung $>F$ tabel dengan signifikansi 0,000 lebih kecil dari 0,05. Ini berarti terdapat kontribusi kemampuan numerik dan verbal secara simultan terhadap hasil belajar Matematika peserta didik kelas V SD gugus Petulu tahun pelajaran 2018/2019. Berdasarkan analisis menggunakan komputer diperoleh besarnya $R_{y 123}=0,846$. Hal ini berarti $R_{y 123}$ $=0,85$ signifikan pada $\alpha=0,05$. Dengan besar kontribusi sebesar $71,6 \%$.

Kemampuan numerik dan kemampuan verbal peserta didik samasama memberikan kontribusi terhadap hasil belajar peserta didik. Jika dilihat dari hal tersebut dapat pula dikatakan bahwa kemampuan numeric dan kemampuan verbal seorang peserta didik secara simultan juga berkontribusi terhadap hasil belajar matematika yang dicapai oleh peserta didik.

Implikasi praktis yang dapat dikembangkan dari hasil penelitian ini tidak terbatas pada pembelajaran pada topik yang dieksperimenkan, melainkan dapat diterapkan pada topik-topik yang lain. Beberapa implikasi yang perlu dilakukan antara lain sebagai berikut:

1. Untuk meningkatkan hasil belajar matematika peserta didik, model pembelajaran Think Talk Write (TTW) dapat dijadikan sebagai alternatif untuk pembelajaran di kelas sehingga mereka akan lebih semangat untuk mempelajari materi yang tentunya juga akan berpengaruh pada hasil belajarnya.

2. Model pembelajaran Think Talk Write (TTW) yang telah diuji cobakan pada penelitian ini, diupayakan untuk diterapkan kembali dengan memberikan inovasi-inovasi baru guna mengasah kemampuan peserta didik.

3. Diharapkan model pembelajaran Think Talk Write (TTW) ini dapat dikembangkan pada materi-materi pembelajaran matematika yang lain.

\section{PENUTUP}

Berdasarkan hasil pengujian hipotesis dan pembahasan, dapat ditarik simpulan sebagai berikut.

Hasil uji hipotesis pertama telah berhasil menolak hipotesis nol yang menyatakan bahwa terdapat pengaruh implementasi model pembelajaran Think Talk Write (TTW) terhadap hasil belajar Matematika peserta didik kelas V SD gugus Petulu tahun pelajaran 2018/2019. 
Hasil uji hipotesis kedua telah berhasil menolak hipotesis nol yang menyatakan bahwa dengan pengendalian kemampuan numerik terdapat pengaruh implementasi model pembelajaran Think Talk Write (TTW) terhadap hasil belajar Matematika peserta didik kelas V SD gugus Petulu tahun pelajaran 2018/2019.

Hasil uji hipotesis ketiga telah berhasil menolak hipotesis nol yang menyatakan bahwa dengan pengendalian kemampuan verbal terdapat pengaruh implementasi model pembelajaran Think Talk Write (TTW) terhadap hasil belajar Matematika peserta didik kelas V SD gugus Petulu tahun pelajaran 2018/2019.

Hasil uji hipotesis keempat telah berhasil menolak hipotesis nol yang menyatakan bahwa dengan pengendalian kemampuan numerik dan verbal secara simultan terdapat pengaruh implementasi model pembelajaran Think Talk Write (TTW) terhadap hasil belajar Matematika peserta didik kelas V SD gugus Petulu tahun pelajaran 2018/2019.

Hasil uji hipotesis kelima telah berhasil menolak hipotesis nol yang menyatakan bahwa terdapat kontribusi kemampuan numerik terhadap hasil belajar Matematika peserta didik kelas V SD Gugus Petulu tahun pelajaran 2018/2019.

Hasil uji hipotesis keenam telah berhasil menolak hipotesis nol yang menyatakan bahwa terdapat kontribusi kemampuan verbal terhadap hasil belajar Matematika peserta didik kelas V SD Gugus Petulu tahun pelajaran 2018/2019.

Hasil uji hipotesis ketujuh telah berhasil menolak hipotesis nol yang menyatakan bahwa terdapat kontribusi kemampuan numerik dan verbal secara simultan terhadap hasil belajar Matematika peserta didik kelas V SD gugus Petulu tahun pelajaran 2018/2019.

Berdasarkan temuan-temuan di atas dapat disimpulkan bahwa implementasi model pembelajaran Think Talk Write (TTW) berpengaruh terhadap hasil belajar matematika peserta didik baik sebelum maupun setelah dikendalikan.

\section{DAFTAR RUJUKAN}

Daniyati dan Sugiman. 2015. Hubungan Antara Kemampuan Verbal, Kemampuan Interpersonal, dan Minat Belajar dengan Prestasi Belajar Matematika (PYTHAGORAS: Jurnal Pendidikan Matematika, Volume 10, Nomor 1, Juni 2015, halaman 50-60) diunduh tanggal 6 Juni 2019.

Dantes, Nyoman. 2012. Metode Penelitian. Yogyakarta: Andi.

Fatimah, Siti, dkk. 2015. Pembelajaran Fisika Dengan Pendekatan Problem Based Learning (PBL) Menggunakan Modul dan Buletin Ditinjau dari Kemampuan Verbal dan Motivasi Berprestasi Siswa (JURNAL INKUIRI ISSN: 2252-7893 Volume 2, Nomor 2) halaman 114-120 dalam http://jurnal.fkip.uns.ac.id/index.php/s ains diunduh tanggal 18 Desember 2018.

Gunarti, Esa. 2017. Hubungan Antara Kreativitas, Kemampuan Numerik dan Sikap Siswa Terhadap Pelajaran Matematika dengan Prestasi Belajar Matematika Siswa Kelas VIII Smp Negeri Se-Kecamatan Pundong (UNION: Jurnal Pendidikan Matematik Volume 5 Nomor 1, Maret 2017) dalam

https://www.researchgate.net/publicati on/328363491 HUBUNGAN ANTAR A KREATIVITAS KEMAMPUAN NU MERIK DAN SIKAP SISWA TERH ADAP PELAJARAN MATEMATIKA DENGAN PRESTASI BELAJAR MA TEMATIKA SISWA KELAS VIII SM $P$ NEGERI SE-

KECAMATAN PUNDONG/download diunduh pada 18 Desember 2018.

Irawan, A dan Kencanawati. 2016, Peranan Kemampuan Verbal dan Kemampuan Numerik terhadap Kemampuan Berpikir Kritis Matematika, (Aksioma Vol. 5, No. 2, 2016), hlm. 111 dalam ummetro.ac.id diunduh 18 Desember 2018. 
Irawan, Ari. (2015). Pengaruh kecerdasan numerik dan penguasaan konsep matematika terhadap kemampuan berpikir kritik matematika. Jurnal Formatif, 4 (1): 46-55.Iskandar (2010)

Kusuma, D.V. dan Budiono. 2015. Kemampuan Verbal, Numerik dan Prestasi Belajar Matematika Siswa SD di Kecamatan Ngemplak (Ekuivalen dalam https://docplayer.info/43386579Kemampuan-verbal-numerik-danprestasi-belajar-matematika-siswa-sddi-kecamatan-ngemplak.html) diunduh tanggal 18 Desember 2018.

Lidya, Y, dkk. 2017. Pengembangan Karakter dan Hasil Belajar Kognitif Siswa dengan Pembelajaran Think Talk Write dipadu Problem Based Learning (Jurnal Pendidikan: Teori, Penelitian dan Pengembangan, EISSN: 2502-471x, Volume 2 Nomor 2 dalam http://journal.um.ac.id/index.php/jptpp/ article/view/8515/4123) diunduh 23 Januari 2019.

Utami, Fajar Novia. 2014. Eksperimentasi Model Pembelajaran Think Talk Write (Ttw) Dengan Pendekatan Matematika Realistik (Pmr) Terhadap Prestasi Belajar Matematika Ditinjau Dari Kemampuan Penalaran Matematika Dan Kreativitas Belajar Siswa Smp Se-Kabupaten Wonogiri (Jurnal Elektronik Pembelajaran Matematika ISSN: 2339-1685 Vol.2, No.3, Mei 2014 ) hal 260 - 269 dalam http://jurnal.fkip.uns.ac.id diunduh tanggal 19 Desember 2018.

Siregar, R dan Syafari. 2017. Perbandingan Kemampuan Pemecahan Masalah Matematis Siswa yang Belajar Menggunakan Model Pembelajaran Kooperatif Tipe Think Talk Write dan Think Pair Share di Smp Negeri 1 Tanjung Morawa (JURNAL INSPIRATIF p-ISSN : 2442-8876, e-
ISSN : 2528-0475 Volume 3 Nomor 1) dalam

https://jurnal.unimed.ac.id/2012/index. php/jpmi/article/view/8887/7735

diunduh tanggal 18 Desember 2018.

Sugiyono. 2014. Metode Penelitian Pendidikan Pendekatan Kuantitatif, Kualitatif, dan R\&D. Bandung: Alfabeta

Suharsimi Arikunto. 2006. Dasar-Dasar Evaluasi Pendidikan. Jakarta: Bumi Aksara.

Wirda. 2017. The effect of think talk write (ttw) learning method on the creative thinking ability of the students at primary school (sd) no. 060856 medan, Indonesia. (British Journal of Education Vol.5, No.11, October 2017) pp. 12-28 dalam www.eajournals.org diunduh tanggal 19 Desember 2018. 